\title{
Effect of penicillamine therapy on circulating immune complexes in rheumatoid arthritis
}

\author{
IDRIS MOHAMMED, D. BARRACLOUGH, E. J. HOLBOROW, AND \\ BARBARA M. ANSELL \\ From the MRC Rheumatism Research Unit, Canadian Red Cross Memorial Hospital, \\ Taplow, Maidenhead, Berks
}

\begin{abstract}
Mohammed, I., Barraclough, D., Holborow, E. J., and Ansell, B. M. (1976). Annals of the Rheumatic Diseases, 35, 458-462. Effect of penicillamine therapy on circulating immune complexes in rheumatoid arthritis. The sera of $\mathbf{4 0}$ patients with severe progressive rheumatoid arthritis were examined for the presence of soluble immune complexes before penicillamine therapy was started, and again after treatment for a mean period of 14.4 months. The methods used were radiobioassay (macrophage uptake), Clq-binding capacity, and precipitation by $4 \%$ polyethylene glycol.

Before treatment the sera of 37 patients showed significantly enhanced uptake of ${ }^{125}$ I-labelled aggregated human IgG by guinea pig macrophages. Treatment produced significant falls in mean erythrocyte sedimentation rate, differential agglutination titre, and serum IgG and IgM levels, and enhancing complexes (EC) decreased or disappeared in 20 patients. In 9 patients EC changed to inhibiting complexes, and in 8 EC levels were unchanged. In 6 of 8 patients with cutaneous vasculitis initially, both lesions and EC disappeared. The total protein and the IgG and IgM precipitated from patients' sera by $4 \%$ polyethylene glycol fell significantly on treatment. Antinuclear antibody titres were unchanged by penicillamine, and 3 patients acquired these antibodies during treatment.

These findings suggest that penicillamine treatment in rheumatoid arthritis reduces the level of circulating soluble immune complexes in which IgM rheumatoid factor is a component.
\end{abstract}

After initial reports on the use of penicillamine in treatment of rheumatoid arthritis (Jaffe, 1964, 1970), a recent multicentre controlled trial (Multicentre Trial Group, 1973) confirmed its effectiveness in active rheumatoid arthritis, and it was subsequently shown to have a similar effect to gold (Huskisson and others, 1974). Recent studies (Onyewotu and others, 1975; Nydegger and others, 1975) have shown the presence of circulating soluble immune complexes in some patients with rheumatoid arthritis. This paper describes the effect of penicillamine therapy on circulating immune complexes in rheumatoid patients.

\section{Patients}

Forty patients (15 males, 25 females) with classical or definite rheumatoid arthritis according to ARA criteria

Accepted for publication February 11, 1976.

Correspondence to Dr. B. M. Ansell.
(Ropes and others, 1959) received penicillamine therapys for severe progressive disease often associated with vasculitis. All had a positive latex and/or differentiaP agglutination titre (DAT). Most of the patients also received nonsteroidal anti-inflammatory drugs such as? salicylates or indomethacin, and 12 were on corticosteroids therapy. The majority had previously received gold ore chloroquine, which had been discontinued either because. of side effects or because of lack of effect some times previously. The mean age of the patients was 54.4 years (range 26-79 years), and the duration of rheumatoip arthritis 12.3 years (range 2-29 years). Two serumw samples were available from each patient, the first takep before starting penicillamine therapy (sample I), ando the other after at least 3 months of therapy (sample II) $\frac{\mathbb{\Phi}}{\mathbb{N}}$ Sera were stored at $-20^{\circ}$ and thawed on the day of? testing. The mean duration of penicillamine therapy ato the time of sample II was 14.4 months (range 3-536 months). The usual dose of penicillamine base wasp $500 \mathrm{mg}$ (range 125-1000 mg), according to response to 
Table I Effect of D-penicillamine on ESR, DAT, ANA, and on immunoglobulin and C3 levels in 40 patients

\begin{tabular}{|c|c|c|c|c|}
\hline & $\begin{array}{l}\text { Sample } I^{*} \\
(\text { mean } \pm S D)\end{array}$ & $\begin{array}{l}\text { Sample } I^{*} \\
(\text { mean } \pm S D)\end{array}$ & $\begin{array}{l}t \text { test } \\
\text { paired }\end{array}$ & $\boldsymbol{P}$ \\
\hline $\begin{array}{l}\text { ESR (mm in } 1 \text { hour) } \\
\text { DAT (score) } \\
\text { ANA (score) } \\
\text { IgG (g/l) } \\
\text { IgD (g/l) } \\
\text { IgA (g/l) } \\
\text { IgM (g/l) } \\
\text { C3 (g/l) }\end{array}$ & $\begin{array}{c}65 \pm 28 \\
2.48 \pm 2 \cdot 25 \\
1.53 \pm 1 \cdot 11 \\
16.05 \pm 4.71 \\
0.02 \pm 0.022 \\
3.33 \pm 1.53 \\
2.07 \pm 1.87 \\
1.15 \pm 0.23\end{array}$ & $\begin{array}{c}37 \pm 23 \\
1.65 \pm 1.96 \\
1 \cdot 88 \pm 1.42 \\
14 \cdot 41 \pm 4 \cdot 13 \\
0.02 \pm 0.021 \\
3.06 \pm 1.79 \\
1 \cdot 37 \pm 1 \cdot 21 \\
1 \cdot 10 \pm 0.19\end{array}$ & $\begin{array}{l}6 \cdot 54 \\
2 \cdot 72 \\
1 \cdot 80 \\
2 \cdot 72 \\
0 \cdot 18 \\
1 \cdot 47 \\
4 \cdot 91 \\
1 \cdot 31\end{array}$ & $\begin{array}{l}<0.001 \\
<0.01 \\
0 \cdot 1<\mathrm{P}<0.05 \\
<0.01 \\
\mathrm{NS} \\
\mathrm{NS} \\
<0.001 \\
\mathrm{NS}\end{array}$ \\
\hline
\end{tabular}

*Sample I: at or before starting penicillamine therapy; sample II: mean of 14.4 months after starting penicillamine therapy.

therapy. In some patients this was administered as the hydrochloride.

A group of 11 patients with rheumatoid arthritis who had positive latex or DAT tests but who were not considered to have severe enough disease to warrant treatment with penicillamine, gold, chloroquine, corticosteroids, or immunosuppressive drugs was also studied. The mean age of this control group was $56 \cdot 3$ years (range 41-74 years) and the mean duration of disease $9 \cdot 1$ years $(2-23$ years). The mean erythrocyte sedimentation rate (ESR) in this group was significantly lower $(P<0.01)$ than in the main study group at the onset of penicillamine therapy (Table I).

\section{Methods}

The latex test was done by the method of Singer and Plotz (1956), at a serum dilution of 1:20. DAT was as described by Bywaters and Scott (1960), and a titre of $1: 16$ or greater taken as positive. For statistical purposes, results were scored 0 if less than $1: 16,1$ if $1: 16,2$ if $1: 32$, and so on. Serum immunoglobulins were measured by the Mancini technique (Mancini, Carbonara, and Heremans, 1965) as was serum C3. Antinuclear antibody (ANA), smooth muscle, mitochondrial, gastric parietal cell, and skeletal muscle antibodies were looked for by immunofluorescence (Johnson and Holborow, 1973). ANA titres were scored as follows 6 units or less $=0$, $25=1,100=2$, etc.

\section{DETECTION OF IMMUNE COMPLEXES}

Three methods were used. (1) A radiobioassay with guinea-pig peritoneal macrophages as modified by Mohammed, Thompson, and Holborow (1976). (2) A modified Clq-binding test (Zubler and others, 1975). (3) A modified polyethylene glycol (PEG) precipitation test (Creighton, Lambert, and Miescher, 1973) in which equal volumes of $1: 5$ serum and $8 \%$ PEG (molecular weight 6000 ) were mixed, and the total protein precipitated measured by the method of Lowry (Lowry and others, 1951 ) or by Mancini's method.

\section{Results}

The effect of penicillamine on ESR, DAT, ANA, immunoglobulins, and $\mathrm{C} 3$ is shown in Table $\mathrm{I}$. There was a significant fall in both ESR and DAT, and in serum IgG and IgM levels. The changes in the IgA and IgD levels were not significant. The serum C3 levels before treatment were within normal range, and did not change during treatment. Table II shows the ANA results. It will be seen that there was a tendency for patients negative before treatment to acquire positive ANA tests, and also a tendency for ANA titres to rise, although overall titres did not reach significance.

\section{IMMUNE COMPLEXES}

\section{Radiobioassay}

Inhibiting complexes (range $20-30 \%$ ) only were detected in the sera of 5 of the 11 control patients. The pretreatment sera of 37 of the 40 treated patients ( $79 \%$ ) significantly enhanced uptake of ${ }_{125}$ I-labelled heat aggregated human IgG by guineapig peritoneal macrophages. This agreed with previous findings in severe seropositive rheumatoid arthritis (Onyewotu and others, 1975), and contrasted with the findings in systemic lupus erythematosus, where inhibition of uptake by patients' sera is the rule (Onyewotu, Holborow, and Johnson,

Table II ANA titres before and after penicillamine treatment

\begin{tabular}{|c|c|c|c|c|c|c|c|}
\hline & \multicolumn{6}{|c|}{ ANA titre $(\mu \mathrm{m} / \mathrm{ml})$} & \multirow{2}{*}{$\begin{array}{l}\text { Total } \\
\text { +ve }\end{array}$} \\
\hline & $<25$ & 25 & 100 & 400 & 1600 & $>1600$ & \\
\hline $\begin{array}{l}\text { Pretreatment } \\
\text { Post-treatment }\end{array}$ & $\begin{array}{l}14 \\
12\end{array}$ & $\begin{array}{l}18 \\
18\end{array}$ & $\begin{array}{l}8 \\
6\end{array}$ & $\begin{array}{l}0 \\
1\end{array}$ & $\begin{array}{l}\mathbf{0} \\
\mathbf{2}\end{array}$ & $\begin{array}{l}0 \\
1\end{array}$ & $\begin{array}{l}26 \\
28\end{array}$ \\
\hline
\end{tabular}


1974). The levels of enhancement and inhibition found and the changes seen during the study are shown in Fig. 1 and Table III. Of the remaining 3 patients, 2 had inhibiting complexes and the serum of one gave neither enhancement nor inhibition. The trend after treatment (Table IV) was for the EC to disappear (13 patients), to decrease (7 patients), or be replaced by inhibiting complexes ( 9 patients). In 8 patients EC were either slightly increased or remained at the same level. Thus a change in the level or character of the complexes in the serum was seen in $79 \%$ of patients as a result of therapy.

\section{PEG precipitation}

In the penicillamine group the mean total protein precipitated by $4 \%$ PEG fell from $7.0 \mathrm{mg} / \mathrm{ml}$ (range

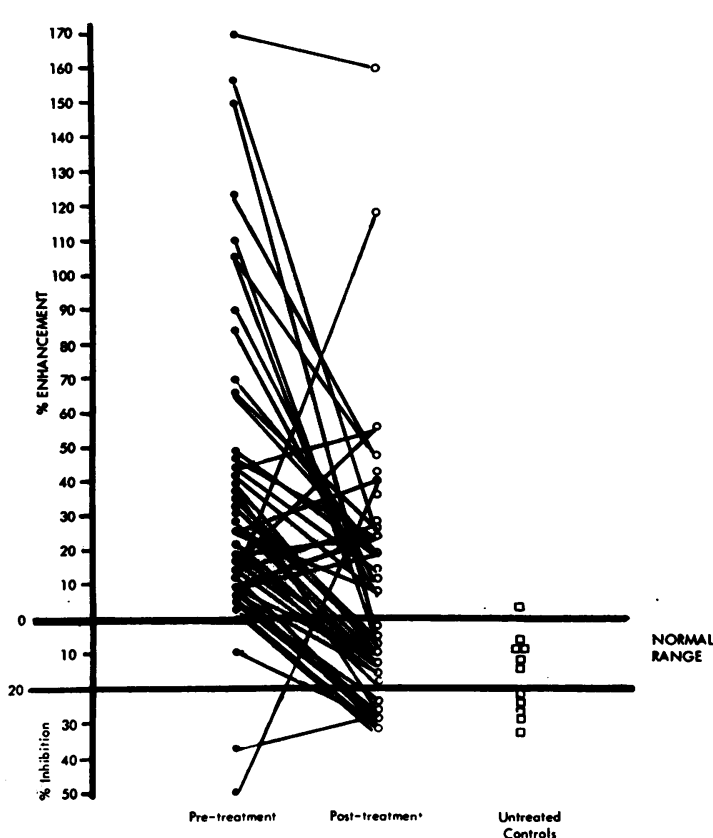

FIG. 1 Effect of penicillamine therapy on immune complexes in rheumatoid arthritis

Table III Results of radiobioassay in 40 penicillamine-treated $R A$ patients

\begin{tabular}{|c|c|c|}
\hline & Pre-treatment & Post-treatment \\
\hline $\begin{array}{l}\% \text { Enhancement } \\
6-50 \\
50-100 \\
>100\end{array}$ & $\begin{array}{r}25 \\
5 \\
7\end{array}$ & $\begin{array}{r}13 \\
0 \\
2\end{array}$ \\
\hline Total & 37 & $\overline{15}$ \\
\hline $\begin{array}{l}\text { \% Inhibition } \\
\text { Normal } \\
21-50\end{array}$ & $\begin{array}{l}1 \\
2\end{array}$ & $\begin{array}{l}13 \\
10\end{array}$ \\
\hline Total & 3 & 23 \\
\hline
\end{tabular}

$0-22$ ) before treatment to $4.5 \mathrm{mg} / \mathrm{ml}$ (range $0-12 \cdot 1$ ) $\frac{\text { गु }}{\widehat{(}}$ after treatment (Fig. 2). Both IgG and IgM were detected by Mancini's method in the redissolved $\square$ precipitates. Quantitative measurement showed a ?. significant fall in IgG in the precipitates, from $\overrightarrow{\vec{F}}$ $32.8 \mathrm{mg}$ to $20.7 \mathrm{mg}$. Insufficient material was $\stackrel{9}{9}$ available to measure the total IgM precisely, but $\stackrel{0}{\mathrm{C}}$ 16 of the 40 PEG precipitates obtained from pre- $\frac{\bar{F}}{\bar{n}}$ treatment sera contained $>18 \mathrm{mg}$ IgM, and only $9 \frac{\sigma}{\vec{\sigma}}$ reached this level in the post-treatment precipitates. $\unrhd$ In the control group 4\% PEG produced no precipitates.

Table IV Change of complex type after penicillamine treatment

\begin{tabular}{|c|c|c|c|}
\hline Pre-treatment & Post-treatment & $n$ & $\%$ \\
\hline $\begin{array}{l}\text { Enhancing } \\
\text { Enhancing } \\
\text { Enhancing } \\
\text { Enhancing }\end{array}$ & $\begin{array}{l}\text { Normal } \\
\text { Inhibiting } \\
\text { Less enhancing } \\
\text { Increased enhancing/ } \\
\text { or no change }\end{array}$ & $\begin{array}{r}13 \\
9 \\
7 \\
8\end{array}$ & $\begin{array}{l}32 \cdot 5 \\
22 \cdot 5 \\
17 \cdot 5 \\
20 \cdot 0\end{array}$ \\
\hline $\begin{array}{l}\text { Inhibiting } \\
\text { Normal }\end{array}$ & $\begin{array}{l}\text { Enhancing } \\
\text { Inhibiting }\end{array}$ & $\begin{array}{l}1 \\
1\end{array}$ & $\begin{array}{l}5 \cdot 0 \\
2 \cdot 5 \frac{9}{0}\end{array}$ \\
\hline Total & & 40 & 100 \\
\hline
\end{tabular}

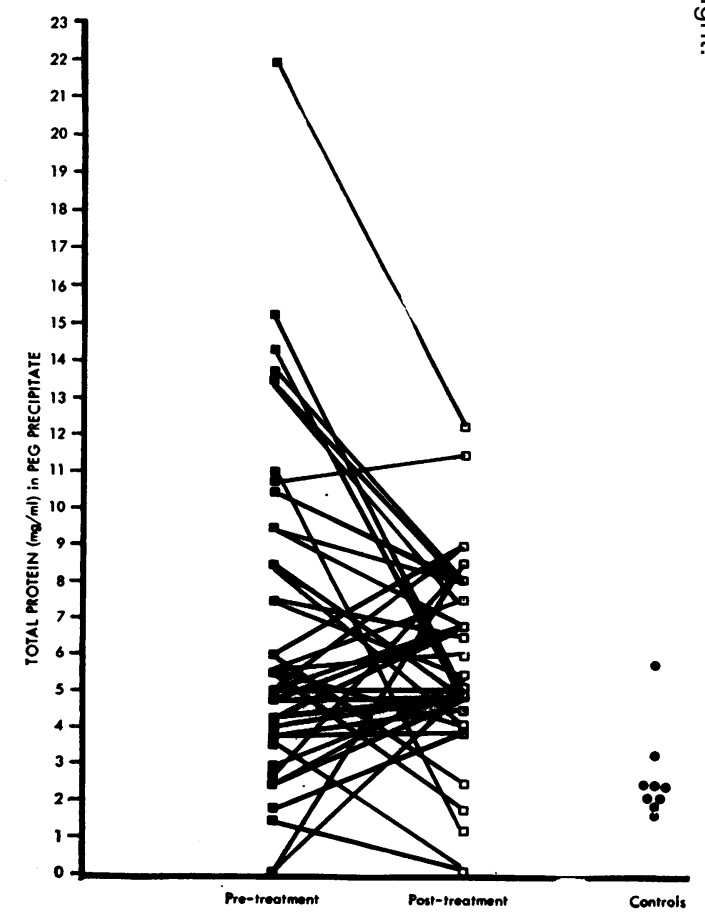

FIG. 2 Effect of penicillamine therapy on total protein precipitated by $4 \%$ PEG (Lowry method) 


\section{VASCULITIS}

At the outset of treatment 8 patients had clinical evidence of cutaneous vasculitis (usually nail fold or finger tip lesions). 7 of these had EC, the other had no detectable complexes. After treatment 6 of these patients had lost their vasculitic lesions, and in these $6 \mathrm{EC}$ had disappeared. Of the 2 with persistent vasculitis, 1 showed a reduction in EC $(107 \%-43 \%)$ and in the other EC had disappeared from the serum. One patient developed vasculitic lesions during treatment and showed an increase in EC $(29 \%-40 \%)$.

\section{NODULES}

Seventeen patients were noted to have subcutaneous nodules when treatment was started. 15 of these had EC, one inhibiting complexes, and one no complexes. At the time of the second serum sample, however, only 9 still had nodules and in 6 of these EC were still present, while in 3 EC had changed to inhibiting complexes. Of the 8 whose nodules had disappeared, EC persisted in 3 , and changed to inhibiting in 5.

\section{Discussion}

This study confirms that penicillamine therapy produces clinical improvement and reduces disease activity. The chief changes in laboratory findings (Table I) were a marked fall in ESR, and significant reductions in the serum IgM and IgG levels, and in the DAT. These findings are similar to those reported by the Multicentre Trial Group (1973) and by Bluestone and Goldberg (1973).

In contrast with the fall in DAT levels, the mean ANA score showed a rise which bordered on significance, and 3 patients developed high titres of ANA during treatment. Penicillamine has been reported to induce a lupus-like syndrome (Harpey and others, 1971) but there were no clinical features to suggest this in any of our patients. In our previous study (Onyewotu and others, 1975) of a randomly selected group of rheumatoid patients, EC were found principally in patients with vasculitis.
The treated patients in the present study, who were selected on the basis of disease severe enough to warrant penicillamine therapy initially showed a high incidence of EC, irrespective of the presence of vasculitis at the time of starting therapy. This probably reflects their greater disease severity, but may also be partly due to the greater sensitivity of the modified radiobioassay method used (Mohammed and others, 1976), which gives higher levels of enhancing complexes than the method originally described. A comparison with results by the C1qbinding method obtained on the pretreatment sera from this study reported elsewhere (Mohammed and others, 1976) shows good agreement between the two methods. It is of interest that the tendency of the EC to fall in amount was paralleled by a fall in DAT, IgM and IgG levels, and also by a significant reduction in the protein precipitated by $4 \%$ PEG from the sera.

These findings suggest that the beneficial effects of penicillamine therapy in rheumatoid arthritis are at any rate partly attributable to a reduction in the level of circulating soluble immune complexes in which IgM rheumatoid factor is a component. They also indicate that in a considerable proportion of patients with rheumatoid arthritis, immune complexes play an important immunopathogenetic role not only extravascularly in the affected joints but also intravascularly in the circulation.

The fact that ANA titres were unaffected by penicillamine, and indeed showed a tendency to rise, may indicate that while complexes consisting of Ig components are reduced in amount, one effect of treatment may be to induce formation of other complexes involving nuclear antigens. Dawkins, Zilko, and Owen (1975) have pointed out that penicillamine may induce a variety of autoantibodies and the change from EC to inhibiting complexes seen in 9 of the patients during treatment is consistent with such an explanation. The possible contribution of autoantibodies to the renal involvement which may result from penicillamine treatment requires further investigation.

\section{References}

Bluestone, R., AND Goldberg, L. S. (1973) Ann. rheum. Dis., 32, 50 (Effect of D-penicillamine on serum immunoglobulins and rheumatoid factor)

Bywaters, E. G. L., AND ScoTT, F. E. T. (1960) 'Rheumatism and the connective tissue diseases' in 'Recent Advances in Clinical Pathology,' Series III, ed. S. C. Dyke, p. 278. Churchill, London

Creighton, W. D., Lambert, P. H., AND Miescher, P. A. (1973) J. Immunol., 3, 1219 (Detection of antibodies and soluble antigen-antibody complexes by precipitation with polyethylene glycol)

Dawkins, R. L., Zilko, P. J., AND Owen, E. T. (1975) Brit. med. J., 4, 759 (Penicillamine therapy, antistriational antibody, and myasthenia gravis)

Harpey, J. P., Castle, B., Moulias, R., AND Goust, J. M. (1971) Lancet, 1, 292 (Lupus-like syndrome induced by D-penicillamine in Wilson's disease) 
Huskisson, E. C., Gibson, T. J., Balme, H. W., Berry, H., Burry, H. C., Grahame, R., Dudley hart, F., Henderson, D. R. F., AND Wojtulewski, J. A. (1974) Ann. rheum. Dis., 33, 532 (Trial comparing D-penicillamine and gold in rheumatoid arthritis. Preliminary report)

JAFFE, E. A. (1964) Ann. intern. Med., 61, 556 (Rheumatoid arthritis with arteritis: report of a case treated with penicillamine)

_ (1970) Arthr. and Rheum., 13, 436 (The treatment of rheumatoid arthritis and necrotising vasculitis with penicillamine)

Johnson, G. D., AND Holborow, E. J. (1973) In 'Handbook of Experimental Immunology', ed. D. M. Weir, Vol. 1 Chap. 18. Blackwell Scientific Publications, Oxford

Lowry, O. H., Rosebrough, N. J., FarR, A. L., AND Randall, R. J. (1951) J. biol. Chem., 193, 265 (Protein measurement with the Folin phenol reagent)

Mancini, G., Carbonara, A. O., AND Heremans, J. F. (1965) Immunochemistry, 2, 235 (Immunological quantitation of antigens by single radial immunodiffusion)

Mohammed, I., Thompson, B., AND Holborow, E. J. (1976) Ann. rheum. Dis., Suppl. (in press) (Radiobioassay for immune complexes using macrophages)

Multicentre Trial Group (1973) Lancet, 1, 275 (Controlled trial of d(-) penicillamine in severe rheumatoid arthritis)

Nydegger, U., IzUi, S., Zubler, R., Lambert, P. H., AND Miescher, P. A. (1975) 'Studies on the biological relevance of immune complexes' in 'The Immunological Basis of Connective Tissue Disorders', p. 85. North Holland, Amsterdam

ONYeWOTU, I. I., Holborow, E. J., AND Johnson, G. D. (1974) Nature, 248, 156 (Detection and radioassay of soluble circulating immune complexes using guinea pig peritoneal exudate cells)

- Johnson, P. M., Johnson, G. D., AND Holborow, E. J. (1975) Clin. exp. Immunol., 19, 267 (Enhanced uptake by guinea pig macrophages of radio iodinated human aggregated immunoglobulin $G$ in the presence of sera from rheumatoid patients with cutaneous vasculitis)

Ropes, M. W., Bennett, G. A., CoBb, S., JACOX, R., AND Jessor, R. A. (1959) Bull. rheum. Dis., 9, 175 (Diagnostic criteria for rheumatoid arthritis, 1958 revision)

Singer, J. M., AND Plotz, C. M. (1956) Amer. J. Med., 21, 888 (The latex fixation test. I. Application to serologic diagnosis of rheumatoid arthritis)

Zubler, R. H., LANGe, G., LAMBert, P. H., AND Miescher, P. A. (1976) J. Immunol., 116, 232 (Detection of immune complexes in unheated sera by a modified ${ }^{125} \mathrm{I}-\mathrm{C}_{1 \mathrm{q}}$ binding test) 